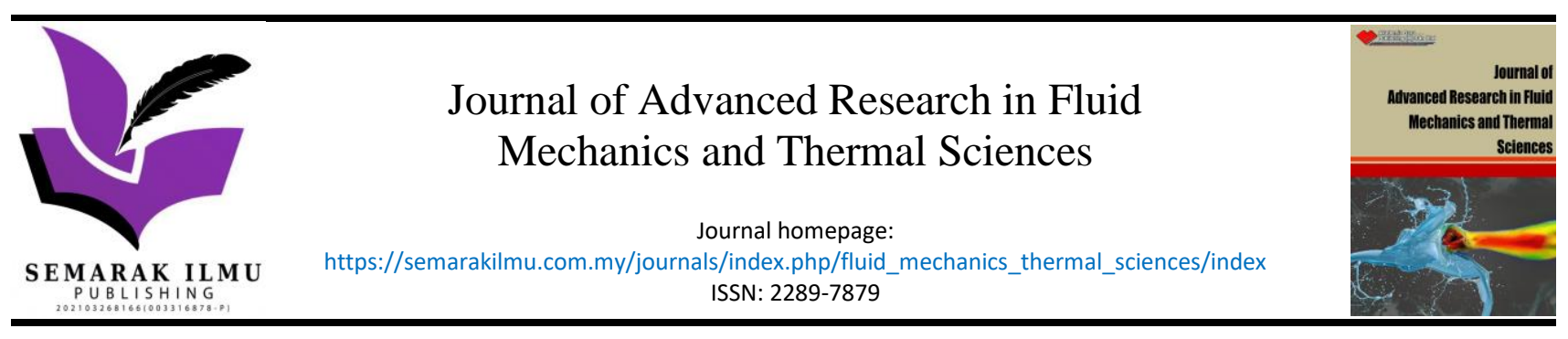

\title{
Performance of Split-type Air Conditioner under Varied Outdoor Air Temperature at Constant Relative Humidity
}

\author{
Windy H. Mitrakusuma ${ }^{1}$, Apip Badarudin ${ }^{1}$, Susilawati ${ }^{1}$, Hafidz Najmudin ${ }^{2}$, Andriyanto Setyawan ${ }^{1, *}$ \\ Department of Refrigeration and Air Conditioning Engineering, Politeknik Negeri Bandung, Bandung 40012, Indonesia \\ Balai Besar Bahan dan Barang Teknik, Bandung, Indonesia
}

ARTICLE INFO

\section{Article history:}

Received 4 July 2021

Received in revised form 26 November 2021

Accepted 15 December 2021

Available online 30 December 2021

\section{Keywords:}

Cooling capacity; energy efficiency ratio; outdoor air temperature; power consumption

\section{ABSTRACT}

\section{Introduction}

Operating condition has an important effect on the performance of an air conditioning unit. The main parameters for the operating condition of an air conditioning unit are discharge temperature, discharge pressure, condensing temperature, suction temperature, and suction pressure.

High discharge and high condensing temperature and pressure can cause performance degradation of an air conditioning unit. They cause higher energy consumption, lower cooling capacity, lower heat rejected by the condenser, and lower COP (coefficient of performance) [1]. Studies for improving the performance of air conditioning systems are needed because its portion of energy consumption in buildings is very high. Jahangeer et al., [2] and Kalkan et al., [3] reported that energy for building air conditioning is in a range of 30 to $45 \%$ of total energy need. For hot regions, the energy demand for air conditioning could reach $70 \%$ [4].

\footnotetext{
* Corresponding author.

E-mail address: andriyanto@polban.ac.id
}

https://doi.org/10.37934/arfmts.90.2.4254 
High outdoor temperature contributes significantly to the high discharge and condensing temperature. An increase of discharge temperature from 83 to $92^{\circ} \mathrm{C}$ caused by the increase environment temperature from 24 to $33^{\circ} \mathrm{C}$ was reported [5]. This fact was resulted from an experiment on a water chiller with R22, R422D, and R417A. In relation to discharge temperature, Oruç et al., [6] noted the decrease of cooling capacity from 1600 to $1400 \mathrm{~W}$ and increase of power consumption from 635 to $650 \mathrm{~W}$ of a split air conditioner with R417A when the ambient temperature was varied from 35 to $41^{\circ} \mathrm{C}$. This study also reported a decrease of refrigerant mass flow rate with the increase of ambient temperature. A drop of COP and cooling capacity by $2 \%$ for each increase of ambient temperature by $1^{\circ} \mathrm{C}$ was disclosed from an experiment in a commercial building [1]. It was also reported that the COP could drop from 2.5 to about 2.1 when the ambient temperature increases from 30 to $50^{\circ} \mathrm{C}$ [7]. The data was recorded from an experimental study of an air conditioner with 4circuit and 8-circuit condenser.

By using R22, R290, R407C, and R410A, Joudi and Al-Amir [8] reported the increase of condensation temperature with the increase of ambient temperature from 35 to $55^{\circ} \mathrm{C}$. The highest condensation temperature of $\mathrm{R} 22$ in the range of $57.5^{\circ} \mathrm{C}$ to $65^{\circ} \mathrm{C}$ was noted in this experiment. This data was obtained from a study on 2 TR air conditioning unit. As well as condensation temperature, the compression ratio also increases from 4.7 to 4.85 . It was also reported that the cooling capacity decrease from $7.5 \mathrm{~kW}$ to $6.4 \mathrm{~kW}$. With the same ambient temperature increase, the power consumption of system with R290 increases from 2.2 to $2.75 \mathrm{~kW}$. For system with R410A, power consumption increases from 2.5 to $3.1 \mathrm{~kW}$. An average reduction of COP by about $20.7 \%$ was also reported from this study.

The increase of condensing temperature could also be caused by the reduction of air flow in the condenser caused by air blockage. An increase of energy consumption by $36 \%$ and decrease of cooling capacity by $46 \%$ were reported when an obstacle is installed in the front of condenser at a distance of $10 \mathrm{~cm}$ [9]. The effect of the obstacle decreases with the increase of the distance between the condenser and the obstacle. The effect diminishes when the obstacle was placed at a distance of $50 \mathrm{~cm}$ or more. Elsayed and Hariri [10] reported that a reduction of compressor energy consumption by $10 \%$ was obtained when the air flow rate in the condenser was increased by $50 \%$. This data was validated by an experiment using a 2.64-kW split-type air conditioner.

To minimize the influence of outdoor air temperature on the air conditioning performance, many works have been carried out. A reduction of condenser air temperature by evaporative pads has been studied [11]. This study reported $1.8 \%$ increase of cooling capacity, $11.4 \%$ reduction of energy use, and $10.6 \%$ of COP improvement. Another study on the use of evaporative cooler with cold water in an air-cooled chiller has been carried out [12]. An increase of COP and reduction of the energy used by the compressor were claimed. The overall benefit resulted in this study is higher than the energy needed for producing the cold water. A study using a window air conditioner was also conducted [13]. An evaporative cooler made from grass was used for lowering the condenser air temperature. In this study, a $13 \%$ of reduction of power absorbed by the air conditioner was reported.

As well as air conditioning unit, domestic refrigerator performance is also affected by ambient temperature. An increase of ambient temperature by $1^{\circ} \mathrm{C}$ could increase the energy consumption of a domestic refrigerator up to 7\% [14]. The increase of energy consumption is higher than that of air conditioning system because domestic refrigerator is not equipped with condenser fan for rejecting heat of refrigerant in its condenser. Khan et al., [15] reported an increase of energy consumption of a refrigerator from $0.21 \mathrm{kWh}$ to $0.32 \mathrm{kWh}$ when the ambient temperature increases from 20 to $33^{\circ} \mathrm{C}$.

Low suction temperature and pressure also cause the degradation of refrigeration system performance and higher energy consumption. Experiment with R134a and R152a resulted a significant reduction of cooling capacity and COP with the increase of compression ratio [16]. 
Variation of suction and evaporating temperature and pressure also cause different flow pattern of refrigerant in the evaporator that affect the heat transfer of refrigeration and air conditioning system [17].

In the recent decades, studies related to the effect of ambient temperature on the performance of air conditioning have been extensively carried out. However, there is no publication with regard to specific study for constant relative humidity of outdoor air. The study is aimed to investigate the performance of an air conditioner when the outdoor air temperature is varied and the relative humidity is constant. In this paper, the operating condition and performance of an air conditioner under varied outdoor air temperature and constant relative humidity were discussed. The operating condition covers the suction and discharge temperature, suction and discharge pressure, and condensing temperature. The performance comprises of power consumption, cooling capacity, and energy efficiency ratio (EER).

\section{Methodology}

The operating conditions and performance of the air conditioner with R32 and nominal capacity of $2.6 \mathrm{~kW}$ were tested in a psychrometric chamber. The chamber consists of two main rooms: outdoor compartment and indoor compartment (Figure 1). The outdoor unit of the air conditioner was installed in the outdoor compartment, while the indoor unit was placed in the indoor compartment. When the test was performed, the condition of the outdoor and indoor compartments was controlled. The relative humidity $(\mathrm{RH})$ of the outdoor compartment was maintained at $50 \%$ while the temperature was varied at 24 to $38^{\circ} \mathrm{C}$ with an increment of $2^{\circ} \mathrm{C}$. Meanwhile, the dry-bulb temperature of the indoor compartment was maintained at $27^{\circ} \mathrm{C}$ and its wet-bulb temperature was maintained at $19^{\circ} \mathrm{C}$. At this condition, the humidity ratio of the compartment is $11.82 \mathrm{~g}$ water vapor per kg dry air. The test procedures follow the ISO 5151:2017.

The control of temperature in the outdoor and indoor compartments were performed by cooling coil, heating coil, humidifier, and fan. The cooling coil stabilizes the temperature and humidity in both compartments by absorbing heat and condensing water vapor when the temperature and humidity are higher than the setpoints. On the other hand, the heating coil will add heat to the compartment if its temperature is below setpoint. The humidifier stabilizes the humidity ratio of the compartment by adding water mist when the humidity is lower than its setpoint. The heater and humidifier in the indoor compartment act as sensible and latent load. When the temperature of the compartment drops below $27^{\circ} \mathrm{C}$, the heater will add sensible heat to increase the temperature. Meanwhile, when the humidity ratio of the compartment drops below $11.82 \mathrm{~g}$ of water vapor per kg of dry air, the humidifier will add moisture content in the compartment to the predetermined level. Therefore, the experiment can be carried out even though when the outdoor compartment is set below $27^{\circ} \mathrm{C}$.

The air conditioner consists of 4 main components: compressor, condenser, expansion device, and evaporator. In condenser and evaporator, refrigerant is in vapor and liquid mixture. Two-phase flow is typically found these components. Parameters to be measured in this experiment are drybulb and wet bulb temperature of outdoor compartment, dry-bulb and wet bulb temperature of indoor compartment, supply and return air temperature, volumetric flow rate of supply air, suction temperature, discharge temperature, condensing temperature, and evaporating temperature. These parameters were used for determining the operating conditions and air conditioner performance. Voltage, current, and electric power were also measured to determine the power consumption of the air conditioner under varied outdoor compartment conditions. 


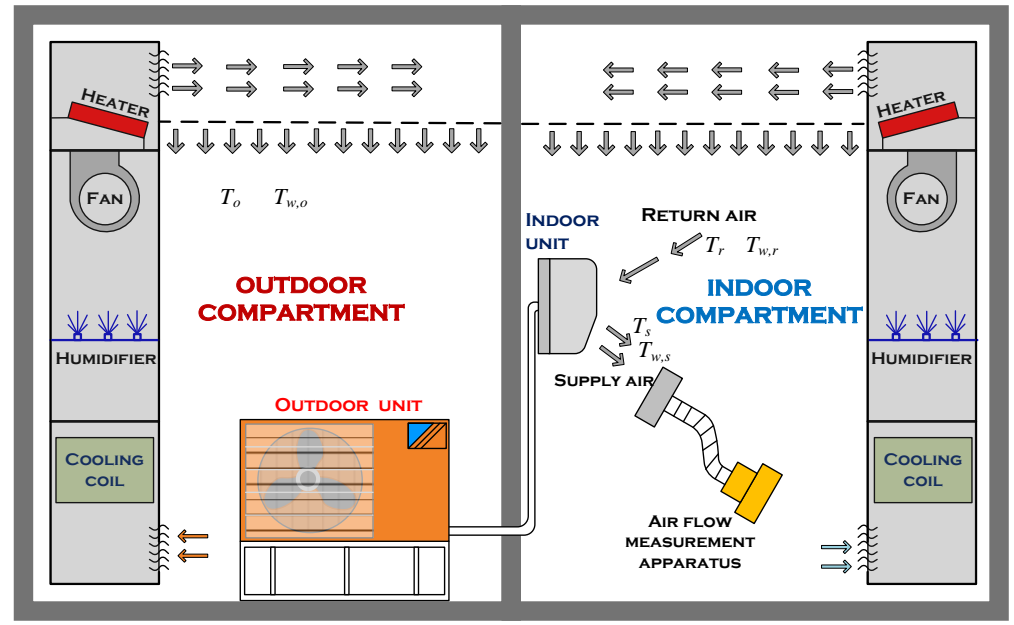

Fig. 1. Diagram of psychrometric chamber

\section{Results and Discussion}

This section discusses two main findings: operating condition and performance of the air conditioning unit. The operating condition involves the suction temperature, discharge temperature, condensing temperature, and evaporating temperature. The performance of the AC unit includes its cooling capacity, input power, and coefficient of performance.

\subsection{Operating Conditions}

\subsubsection{Evaporating temperature}

Evaporating temperature represents the temperature of refrigerant during it evaporates in the evaporator. In this condition, the refrigerant is usually at low temperature and low pressure. At the inlet end of evaporator, the refrigerant is usually in the mixture of liquid and vapor phase, but the liquid portion is dominant [17]. Prior to the outlet, all liquid refrigerant evaporates, and all refrigerant is in the vapor phase. The raw data of evaporating temperature for all range of experiment is plotted in Figure 2. In general, evaporating temperature is low when outdoor temperature is low, and vice versa. The increase of evaporating temperature is most likely caused by the increase of condensing pressure due to the increase of outdoor air temperature. As the condensing pressure increase, the evaporating pressure also increase. This results in the increase of evaporating temperature.

For this experiment, at the highest temperature of outdoor air chamber $\left(38^{\circ} \mathrm{C}\right)$ and relative humidity of $50 \%$, the evaporating temperature is found to be $10.76^{\circ} \mathrm{C}$, corresponding to evaporating pressure of 11.32 bar. Lowering the outdoor chamber temperature to 36 and $34^{\circ} \mathrm{C}$ with constant relative humidity results in the evaporating temperature of refrigerant to 10.18 and $9.37^{\circ} \mathrm{C}$, respectively. It corresponds to evaporating pressure of 11.13 and 10.86 bar. Further reduction of outdoor chamber temperature to 32,30 , and $28^{\circ} \mathrm{C}$ at constant relative humidity gives the evaporating temperature of $9.01,8.38$, and $7.81^{\circ} \mathrm{C}$, respectively. The evaporating pressures for these conditions are $10.75,10.55$, and 10.36 bar. For the lowest outdoor chamber temperature $\left(24^{\circ} \mathrm{C}\right.$ and $\left.50 \% \mathrm{RH}\right)$, the evaporating temperature is $6.95^{\circ} \mathrm{C}$ and the evaporating pressure is $10.1 \mathrm{bar}$.

Figure 2 portrays the profile of evaporating temperature in relation with outdoor air temperature at constant relative humidity of $50 \%$. It is apparent that $14^{\circ} \mathrm{C}$ difference in outdoor air temperature gives $3.81^{\circ} \mathrm{C}$ difference in evaporating temperature. For the experiment under constant $\mathrm{RH}$ and varied $\mathrm{DBT}$, the relation between outdoor air temperature and evaporating temperature can be expressed as 
$t_{E}=0.274 t_{O A}+0.235$

where $t_{E}$ is evaporating temperature and $t_{O A}$ is outdoor air temperature. Eq. (1) implies that the evaporating temperature decreases by $0.27^{\circ} \mathrm{C}$ per $1^{\circ} \mathrm{C}$ decrease of outdoor air temperature.

\subsubsection{Suction temperature}

Refrigerant suction temperature was measured in the suction line connecting the evaporator and compressor. Suction temperature is generally slightly higher than that of evaporating temperature. Therefore, the increase of evaporating temperature leads to the increase of suction temperature.

The raw data of suction temperature is depicted in Figure 3. At the highest temperature of outdoor chamber $\left(38^{\circ} \mathrm{C}\right)$, the average suction temperature is $11.46^{\circ} \mathrm{C}$. It $0.7^{\circ} \mathrm{C}$ higher than that of evaporating temperature. When the outdoor chamber temperature is cooled to 36 and $34^{\circ} \mathrm{C}$, the suction temperature changes to 11.29 and $11.4^{\circ} \mathrm{C}$, respectively. Compared to evaporating temperature, it 1.11 and $1.79^{\circ} \mathrm{C}$ higher. Suction temperature of $10.89,10.74$, and $10.59^{\circ} \mathrm{C}$ were found when the temperature of outdoor chamber was reduced to 32,30 , and $28^{\circ} \mathrm{C}$, respectively. Finally, the suction temperature drops to $10.36^{\circ} \mathrm{C}$ when the outdoor chamber temperature was reduced to $24^{\circ} \mathrm{C}$.

For this experiment, $14^{\circ} \mathrm{C}$ reduction of outdoor chamber temperature results in the decrease of suction temperature by 1.10 . In other words, each $1^{\circ} \mathrm{C}$ of change of outdoor air temperature results in the change of suction temperature by $0.081^{\circ} \mathrm{C}$. Under constant $\mathrm{RH} 50 \%$, expression for the effect of outdoor air temperature on the suction temperature can be written as in Eq. (2)

$t_{S}=0.081 t_{O A}+8.349$

where $t_{s}$ is refrigerant suction temperature. For a comparison, Joudi and Al-Amir [8] reported that each $1^{\circ} \mathrm{C}$ increase of outdoor temperature causes the increase of suction temperature by $0.06^{\circ} \mathrm{C}$ for R22. The increase of suction temperature by $0.12^{\circ} \mathrm{C}$ and $0.16^{\circ} \mathrm{C}$ were informed for experiment using R407C and R290.

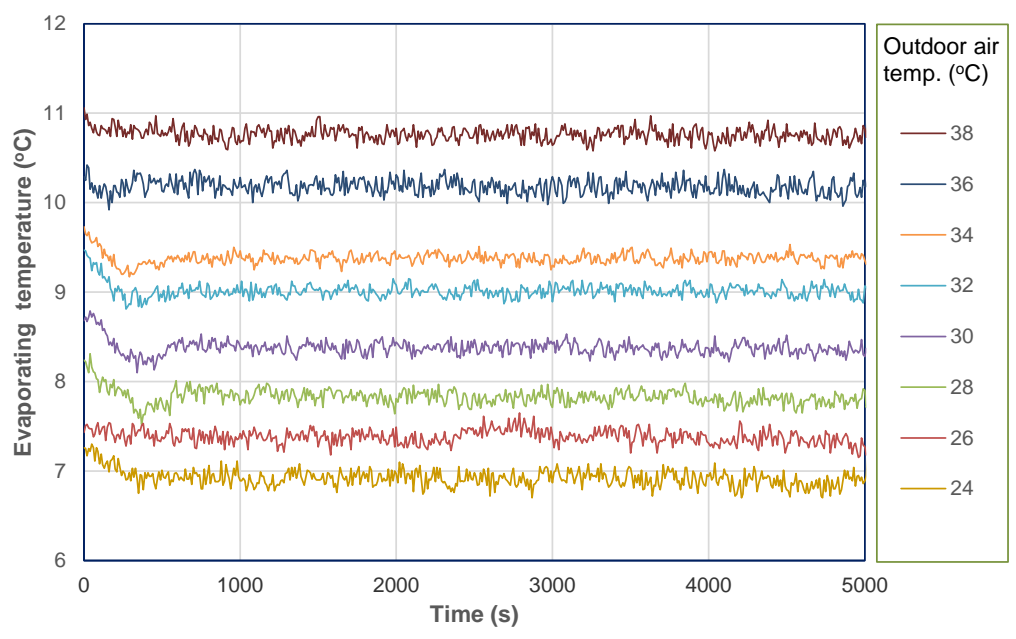

Fig. 2. Evaporating temperature for varied outdoor air temperature 


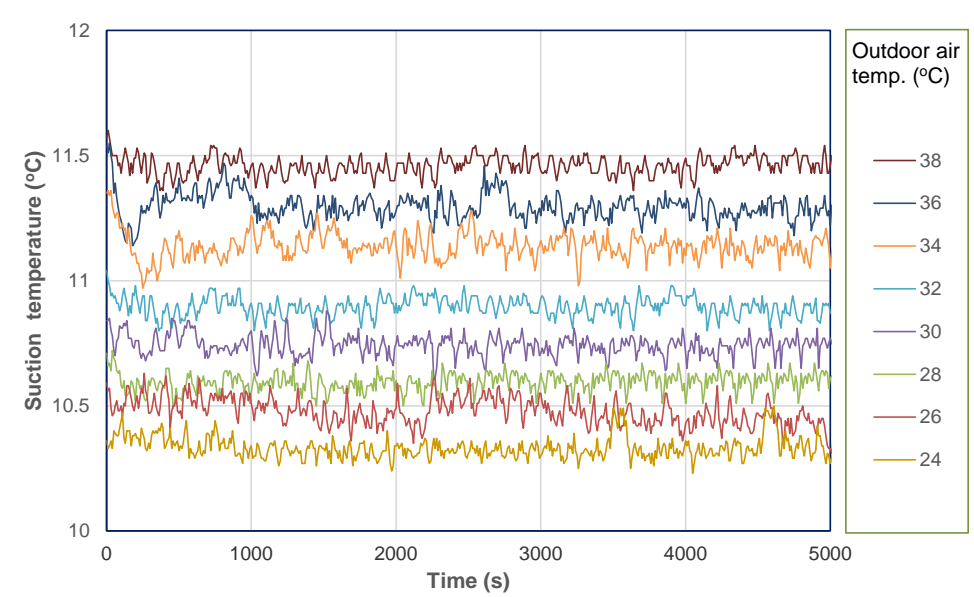

Fig. 3. Suction temperature for varied outdoor air temperature

\subsubsection{Discharge temperature}

The measured discharge temperature for each outdoor chamber temperature is presented in Figure 4. As expected, the higher outdoor chamber temperature gives the higher discharge temperature of refrigerant. When the ambient temperature is high, the refrigerant needs higher temperature in order to dissipate heat to the ambient air. Consequently, the discharge temperature of refrigerant increases with the increase of ambient air temperature.

At $38^{\circ} \mathrm{C}$ of outdoor air temperature and $50 \%$ of $\mathrm{RH}$, the average discharge temperature is $99.98^{\circ} \mathrm{C}$. Lowering the temperature of outdoor air to 36,34 , and $32^{\circ} \mathrm{C}$ at constant $\mathrm{RH}$ results in the decrease of discharge temperature to $97.03,94.83$, and $92.83^{\circ} \mathrm{C}$, respectively. In this range, $6^{\circ} \mathrm{C}$ decrease of outdoor air temperature provides $7.15^{\circ} \mathrm{C}$ decrease of discharge temperature. The next $6^{\circ} \mathrm{C}$ decrease of outdoor air temperature to $26^{\circ} \mathrm{C}$ gives discharge temperature of $86.52^{\circ} \mathrm{C}$, or drops by $6.31^{\circ} \mathrm{C}$. At $24^{\circ} \mathrm{C}$ of outdoor air temperature, the discharge temperature is $85.10^{\circ} \mathrm{C}$. Totally, $14^{\circ} \mathrm{C}$ decrease of outdoor air temperature results in the decrease of discharge temperature by $14.88^{\circ} \mathrm{C}$. Expression for the relation between outdoor air temperature and discharge temperature $\left(t_{D}\right)$ can be expressed as

$t_{D}=1.08 t_{O A}+58.39$

Eq. (3) indicated that each reduction of outdoor air temperature by $1^{\circ} \mathrm{C}$ at constant $50 \% \mathrm{RH}$ gives a reduction of discharge temperature by $1.08^{\circ} \mathrm{C}$.

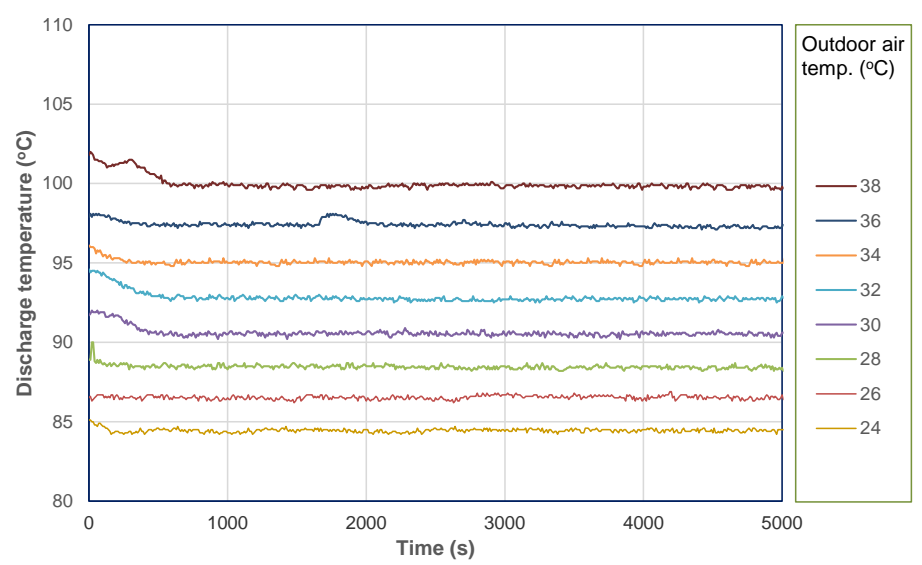

Fig. 4. Discharge temperature for varied outdoor air temperature 


\subsubsection{Condensing temperature}

This parameter represents the temperature of refrigerant when it condenses under constant temperature in the condenser pipe. The measured condensing temperature for all range of experiment is shown in Figure 5. From the experiment, it was found that condensing temperature is higher when the outdoor chamber temperature is higher. In this case, condensing temperature and discharge temperature are related to each other. Therefore, the higher ambient temperature results in the higher discharge and condensing temperature.

For outdoor chamber temperature of $38^{\circ} \mathrm{C}$, the condensing temperature was measured at $40.36^{\circ} \mathrm{C}$ averagely. The average condensing temperature drops to $42.11,40.05$, and $36.66^{\circ} \mathrm{C}$ when the outdoor chamber temperature was set at 36,34 , and $32^{\circ} \mathrm{C}$, respectively. A drop of condensing temperature by $8.7^{\circ} \mathrm{C}$ was found when outdoor chamber temperature was reduced by $6^{\circ} \mathrm{C}$ from 38 to $32^{\circ} \mathrm{C}$. Next setting of outdoor chamber temperature to 30,28 , and $26^{\circ} \mathrm{C}$ provides condensing temperature of $35.11,34.06$, and $32.15^{\circ} \mathrm{C}$, respectively. Finally, outdoor chamber temperature setting to $24^{\circ} \mathrm{C}$ gives condensing temperature of $30.49^{\circ} \mathrm{C}$. In this case, the next reduction of outdoor chamber temperature by $6^{\circ} \mathrm{C}\left(30\right.$ to $24^{\circ} \mathrm{C}$ ) gives the lower reduction of condensing temperature by $4.61^{\circ} \mathrm{C}$. In other words, lower outdoor air temperature has a less significant effect on condensing temperature. The more significant effect is shown in the range of outdoor air temperature from 32 to $36^{\circ} \mathrm{C}$ and the less significant effect is in the range of 30 to $24^{\circ} \mathrm{C}$. Based on the experiment, the effect of outdoor air temperature at constant $\mathrm{RH}$ on the condensing temperature $\left(t_{c}\right)$ can be expressed as

$t_{C}=0.036 t_{O A^{-}}^{2} 1.204 t_{O A}+38.79$

and the linear interpolation gives

$t_{c}=1.0411 t_{O A}+4.761$

Eq. (5) indicates that every $1^{\circ} \mathrm{C}$ increase of outdoor air temperature results an increase of condensing temperature by $1.04^{\circ} \mathrm{C}$. Meanwhile, Joudi and Al-Amir [8] reported the lower increase rate of condensing temperature from their experiment with four different refrigerants.

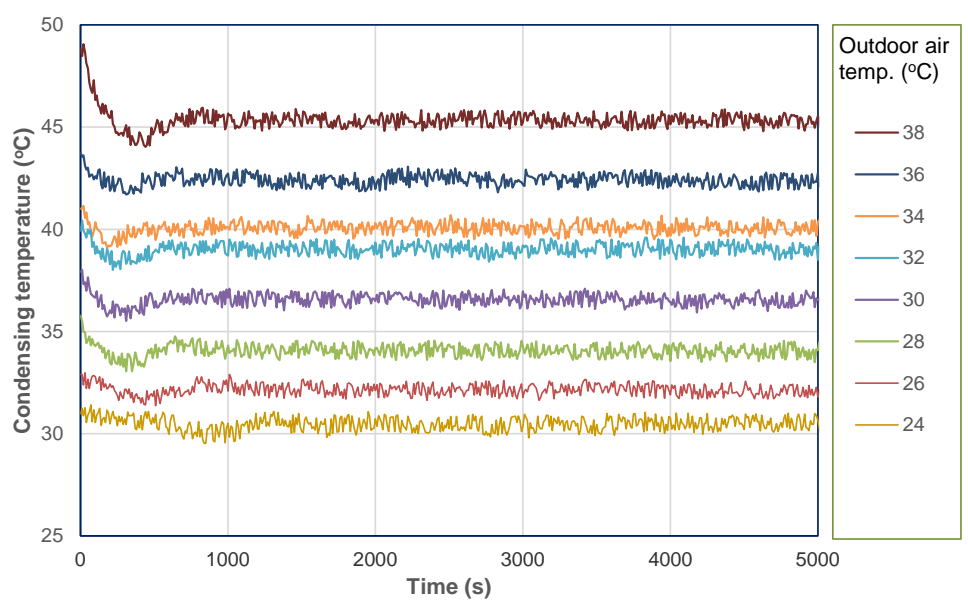

Fig. 5. Condensing temperature for varied outdoor air temperature 


\subsubsection{Suction and discharge pressure}

Suction and discharge pressure express the pressure of vapor refrigerant when it is sucked into and discharged from the compressor. The ratio between the absolute discharge and absolute suction pressure is called as compression ratio for pressure ratio. For the range of outdoor air used in this experiment, the suction pressure is in the range of 10.10 to $11.32 \mathrm{bar}$, while the discharge pressure is in the range of 19.52 to 28.18 bar. The highest suction and discharge pressure are obtained for the highest outdoor air temperature $\left(38^{\circ} \mathrm{C}\right)$. When the outdoor chamber temperature was set at 36,34 , and $32^{\circ} \mathrm{C}$, the suction pressure was found at $11.13,10.86$, and $10.75 \mathrm{bar}$, while the discharge pressure was at $26.27,24.80$, and 22.81 bar, respectively. For outdoor chamber temperature of 32 to $38^{\circ} \mathrm{C}$, the pressure ratio is in the range of 2.12 to 2.49. Experiment for the lower half of outdoor chamber temperature $\left(24\right.$ to $30^{\circ} \mathrm{C}$ ) gives the pressure ratio of 1.94 to 2.08 . As a comparison, range of pressure ratio from 4.22 to 4.75 was reported for $\mathrm{R} 290$ with ambient temperature from 35 to $55^{\circ} \mathrm{C}$ [8]. The higher compression ratio is most likely caused by the higher ambient temperature used in the experiment. Under this condition, the refrigerant needs a higher temperature and pressure for condensation in the condenser. This results in the higher discharge pressure and higher pressure ratio. Figure 6 shows the plot of compression ratio for this experiment as a function of outdoor air temperature.

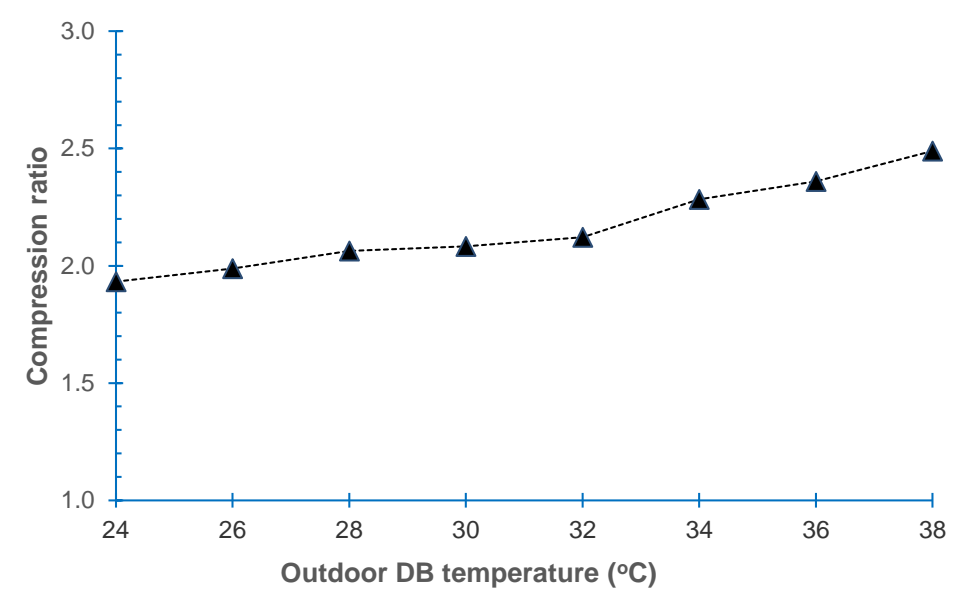

Fig. 6. Compression ratio as a function of outdoor air temperature

\subsection{Air Conditioner Performance}

\subsubsection{Supply air temperature}

The measurement of supply air temperature was taken place at the outlet of evaporator. It measures the temperature of air being supplied to the indoor chamber after being cooled by the evaporator. Figure 7 presents the raw data of supply air temperature for all range of outdoor chamber temperature. Averagely, the supply air has temperature of $14.99,14.94$, and $14.74^{\circ} \mathrm{C}$ for outdoor temperature setting of 38,36 , and $34^{\circ} \mathrm{C}$, respectively. The supply air temperature drops to $14.57,14.40$, and $14.25^{\circ} \mathrm{C}$ when the outdoor chamber temperature setting was changed to 32,30 , and $28^{\circ} \mathrm{C}$, respectively. Further reduction of outdoor chamber temperature to $24^{\circ} \mathrm{C}$ results in supply air temperature of $14.03^{\circ} \mathrm{C}$. The effect of outdoor air temperature on supply air temperature is depicted in Figure 8.

As discussed in Section 3.1.1, the increase of ambient temperature results in the increase of evaporating temperature in the evaporator. As the air flow rate in the evaporator is constant, then 
the temperature of air at the outlet of evaporator will also increase. In this experiment, decreasing outdoor air temperature from by $14^{\circ} \mathrm{C}$ only change the supply air temperature by less than $1^{\circ} \mathrm{C}$. Linear interpolation of the curve in Figure 8 gives a rate of change in supply air temperature by $0.068^{\circ} \mathrm{C}$ per $1^{\circ} \mathrm{C}$ change of outdoor air temperature with constant relative humidity of $50 \%$. The effect of outdoor air on supply air temperature $\left(t_{S A}\right)$ can be expressed in Eq. (6)

$t_{S A}=0.068 t_{O A}+12.41$

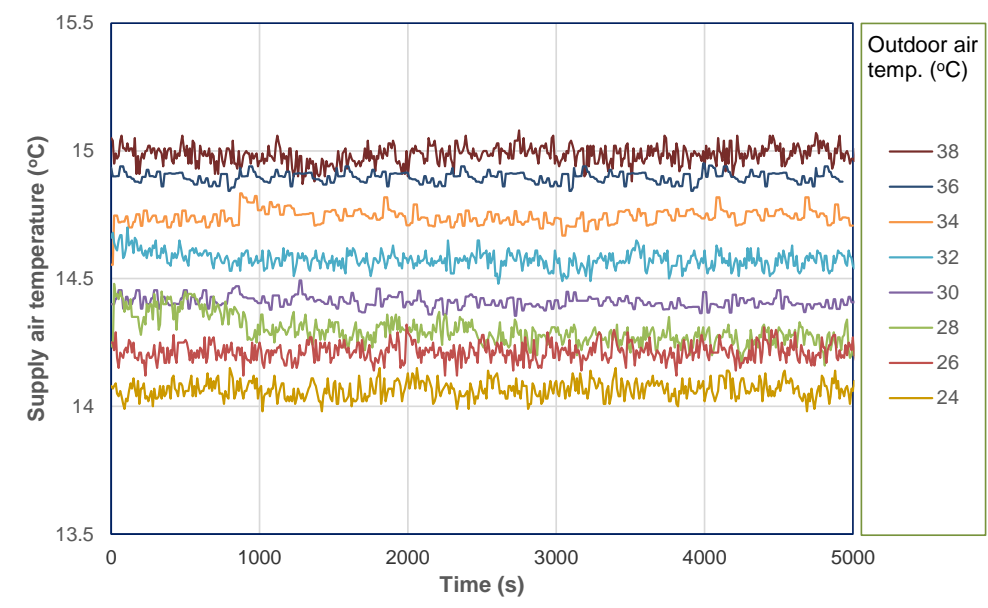

Fig. 7. Supply air temperature for varied outdoor air temperature

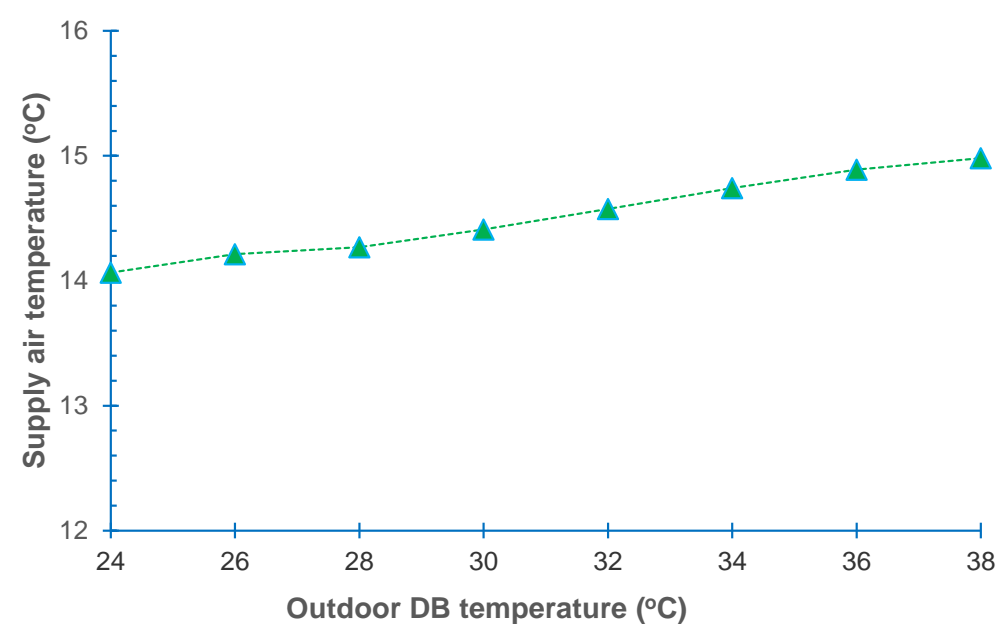

Fig. 8. Average supply air temperature vs outdoor air temperature

\subsubsection{Cooling capacity}

The cooling capacity denotes the ability of the air conditioner to cool the air passes the evaporator. For constant air flow rate over the evaporator, the higher cooling capacity is indicated by the lower supply air temperature. Lower outdoor air temperature provides higher cooling capacity.

At outdoor temperature setting of $24^{\circ} \mathrm{C}$, the cooling capacity was calculated at $2.796 \mathrm{~kW}$. The capacity was reduced to $2.718 \mathrm{~kW}$ (or by $2,8 \%$ ) when the outdoor air temperature setting was changed to $26^{\circ} \mathrm{C}$. Further reduction of cooling capacity to $2.687,2.644$, and $2.587 \mathrm{~kW}$ was obtained when the outdoor air temperature was set at 28,30 , and $32^{\circ} \mathrm{C}$, respectively. Finally, the cooling 
capacity was reduced to $2.42 \mathrm{~kW}$ when the outdoor air temperature was set at $38^{\circ} \mathrm{C}$ (Figure 9). Totally, a drop of cooling capacity by $13.4 \%$ was found for $14^{\circ} \mathrm{C}$ increase of outdoor air temperature. Averagely, the cooling capacity was reduced by $1.0 \%$ per $1^{\circ} \mathrm{C}$ increase of outdoor air temperature with constant relative humidity. As a comparison, Yau and Pean [1] informed a reduction of cooling capacity by $2 \%$ per $1{ }^{\circ} \mathrm{C}$ increase of outdoor air temperature. Meanwhile, Kumbhar et al., [18] reported that the cooling capacity of a chiller decrease by $1.3 \%$ per $1^{\circ} \mathrm{C}$ increase of condensing temperature. Using four refrigerants, Joudi and Al-Amir [8] informed an average reduction of cooling capacity by $1.45 \%$.

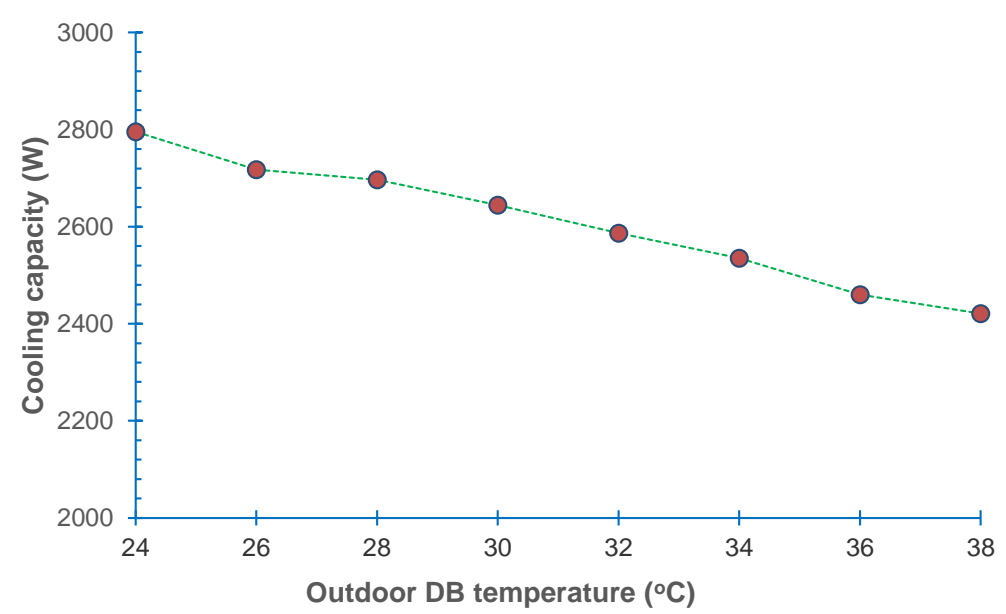

Fig. 9. Cooling capacity vs outdoor air temperature

\subsubsection{Power consumption}

The plot of power consumption of the tested air conditioner is shown in Figure 10. As expected, the air conditioner draws more power when the outdoor air temperature is higher. At high ambient temperature, the refrigerant needs a higher temperature and pressure to be condensed. It requires higher work of compression and higher power absorbed by the compressor.

At the highest outdoor air temperature, the power needed to operate the air conditioner was measured at 998.83 Watts, averagely. The required power drops to 814.0 Watts when the temperature of outdoor chamber was lowered to $24^{\circ} \mathrm{C}$. In this case, $14^{\circ} \mathrm{C}$ of reduction of outdoor air temperature gives the reduction of power consumption by 184.83 Watts. In average, the power consumption increases by $1.6 \%$ for every $1^{\circ} \mathrm{C}$ increase of outdoor air temperature.

The increase of power consumption with the increase of ambient temperature was also informed [19]. Based on their experiment using an automotive air conditioning with R-134a at speed of 1000, 1500, and $2000 \mathrm{rpm}$, they reported an increase of power consumption when the ambient temperature was varied at 30,35 , and $40^{\circ} \mathrm{C}$. Meanwhile, Kumbhar et al., [18] reported an increase of power consumption by $1.92 \%$ per $1^{\circ} \mathrm{C}$ increase of condensing temperature. 


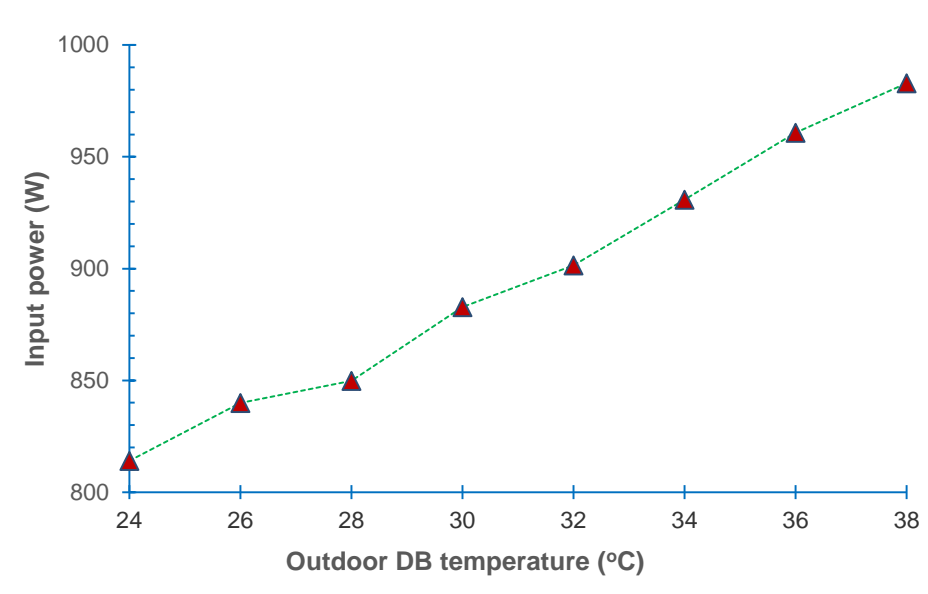

Fig. 10. Power consumption vs outdoor air temperature

\subsubsection{Energy Efficiency Ratio (EER)}

The efficiency of an air conditioning system could be expressed in terms of EER and COP. Energy Efficiency Ratio (EER) is defined as the ratio between the cooling capacity and power absorbed by the air conditioner. In refrigeration system, Coefficient of Performance (COP) is defined as the ratio between the refrigerating effect and the specific work of compression. The plot in Figure 11 shows the effect of outdoor air temperature on the EER of the tested air conditioner under constant outdoor $\mathrm{RH}$. As could be seen, in general, the EER decreases with the increase of outdoor air temperature. For all range of outdoor air temperature, the EER is in the range of 2.42 to 3.44 . Totally, the increase of outdoor air temperature by $14^{\circ} \mathrm{C}$ gives the drop of EER by $29.4 \%$. Using linear approximation, $2.1 \%$ reduction of EER is resulted per $1^{\circ} \mathrm{C}$ increase of outdoor air temperature. Similar data was proposed [1]. As in the cooling capacity, the reduction of COP by about $2 \%$ was resulted per $1^{\circ} \mathrm{C}$ increase of ambient temperature. A study using a window air conditioner with $\mathrm{R} 407 \mathrm{C}$ also resulted in a reduction of COP from about 2.5 to 2.1 when the ambient temperature was varied from 30 to $50^{\circ} \mathrm{C}$ [7]. In this study, the condenser was configured into two: 4-circuit and 8-circuit condenser. The decrease of COP due to the increase of ambient temperature was also informed from an experiment using a cooling unit with direct-current micro compressor and refrigerant R-134a [20]. The COP of the cooling tested under ambient temperature of 25,35 , and $55^{\circ} \mathrm{C}$ were reported at about $1.15,1.1$, and 0.9 , respectively. Another study proposed a decrease of COP by $3.23 \%$ per $1{ }^{\circ} \mathrm{C}$ increase of condensing temperature [18].

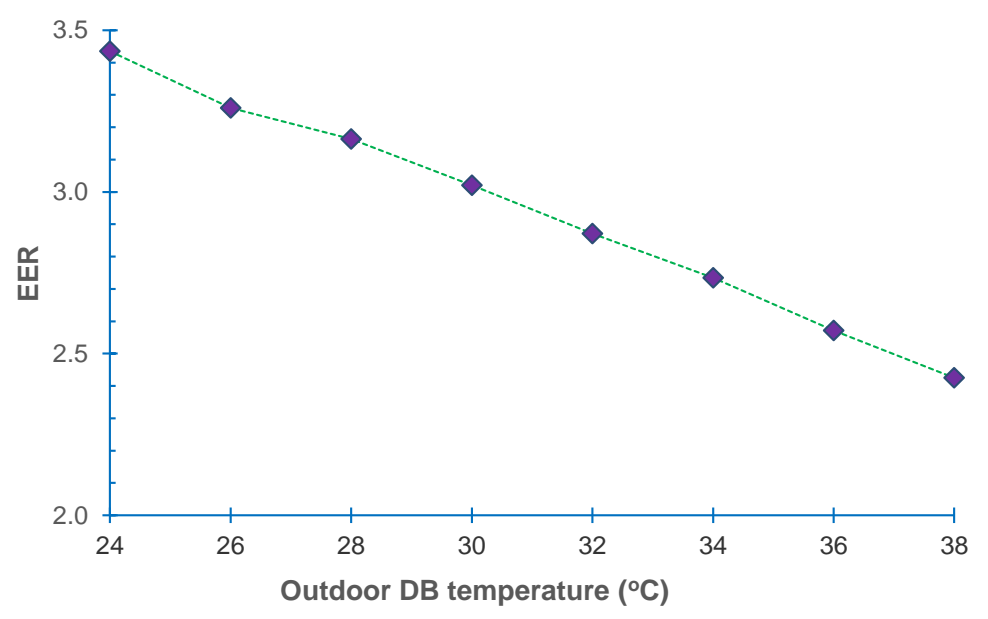

Fig. 11. EER vs outdoor air temperature 


\section{Conclusions}

Investigations on the operating conditions and performance of an air conditioner has been carried out in a controlled psychrometric chamber. Typically, each $1^{\circ} \mathrm{C}$ increase in outdoor air temperature will increase evaporating temperature by $0.27^{\circ} \mathrm{C}$, increase suction temperature by $0.08^{\circ} \mathrm{C}$, increase discharge temperature by $1.08^{\circ} \mathrm{C}$, increase condensing temperature by $1.04^{\circ} \mathrm{C}$, and increase of supply air temperature by $0.068^{\circ} \mathrm{C}$.

The cooling capacity of the air conditioner ranges from $2.42 \mathrm{~kW}$ to $2.796 \mathrm{~kW}$. Each $1^{\circ} \mathrm{C}$ increase of outdoor air temperature reduces the cooling capacity by $1 \%$. The power consumed by the machine is in the range of 814.0 to 998.8 Watts. An increase of power consumption by $1.6 \%$ is obtained for each $1^{\circ} \mathrm{C}$ increase of outdoor air temperature. Later, the EER of the air conditioner drops by $2.1 \%$ for each $1^{\circ} \mathrm{C}$ increase of outdoor air temperature.

\section{Acknowledgement}

The authors thank to Dhiranty Nafiina Irawan and Balai Besar Bahan dan Barang Teknik Bandung for the support during the experiment. The authors would also thank to the (1) Ministry of Education and Culture the Republic of Indonesia, (2) Ministry of Research and Technology/National Research and Innovation Agency of the Republic of Indonesia, and (3) Politeknik Negeri Bandung for the kind supports during the preparation of this paper.

\section{References}

[1] Yau, Y. H., and H. L. Pean. "The performance study of a split type air conditioning system in the tropics, as affected by weather." Energy and Buildings 72 (2014): 1-7. https://doi.org/10.1016/j.enbuild.2013.12.010

[2] Jahangeer, K. A., Andrew AO Tay, and Md Raisul Islam. "Numerical investigation of transfer coefficients of an evaporatively-cooled condenser." Applied Thermal Engineering 31, no. 10 (2011): 1655-1663. https://doi.org/10.1016/i.applthermaleng.2011.02.007

[3] Kalkan, Naci, E. A. Young, and Ahmet Celiktas. "Solar thermal air conditioning technology reducing the footprint of solar thermal air conditioning." Renewable and Sustainable Energy Reviews 16, no. 8 (2012): 6352-6383. https://doi.org/10.1016/i.rser.2012.07.014

[4] Al Horr, Yousef, Bourhan Tashtoush, Nelson Chilengwe, and Mohamed Musthafa. "Operational mode optimization of indirect evaporative cooling in hot climates." Case Studies in Thermal Engineering 18 (2020): 100574. https://doi.org/10.1016/i.csite.2019.100574

[5] Torrella, E., R. Cabello, D. Sanchez, J. A. Larumbe, and Rodrigo Llopis. "On-site study of HCFC-22 substitution for HFC non-azeotropic blends (R417A, R422D) on a water chiller of a centralized HVAC system." Energy and Buildings 42, no. 9 (2010): 1561-1566. https://doi.org/10.1016/i.enbuild.2010.04.001

[6] Oruç, Vedat, Atilla G. Devecioğlu, Uğur Berk, and Ibrahim Vural. "Experimental comparison of the energy parameters of HFCs used as alternatives to HCFC-22 in split type air conditioners." International Journal of Refrigeration 63 (2016): 125-132. https://doi.org/10.1016/j.ijrefrig.2015.11.004

[7] Khalifa, Abdul Hadi N., Johain J. Fataj, and Ali K. Shaker. "Performance study on a window type air conditioner condenser using alternative refrigerant R407C." Engineering Journal 21, no. 1 (2017): $235-243$. https://doi.org/10.4186/ej.2017.21.1.235

[8] Joudi, Khalid A., and Qusay R. Al-Amir. "Experimental Assessment of residential split type air-conditioning systems using alternative refrigerants to R-22 at high ambient temperatures." Energy Conversion and Management 86 (2014): 496-506. https://doi.org/10.1016/j.enconman.2014.05.036

[9] Setyawan, Andriyanto. "Effect of air flow obstruction in a condensing unit on split air conditioner performance." Jurnal Teknologi 82, no. 5 (2020): 23-30. https://doi.org/10.11113/it.v82.1418

[10] Elsayed, Amr O., and Abdulrahman S. Hariri. "Effect of condenser air flow on the performance of split air conditioner." In World Renewable Energy Congress-Sweden; 8-13 May; 2011; Linköping; Sweden, no. 057, pp. 21342141. Linköping University Electronic Press, 2011. https://doi.org/10.3384/ecp110572134

[11] Martínez, Pedro, J. Ruiz, C. G. Cutillas, P. J. Martínez, A. S. Kaiser, and M. Lucas. "Experimental study on energy performance of a split air-conditioner by using variable thickness evaporative cooling pads coupled to the 
$\begin{array}{llllll}\text { condenser." } \quad \text { Applied } & \text { Thermal } & 105 & \text { (2016): }\end{array}$ https://doi.org/10.1016/i.applthermaleng.2016.01.067

[12] Kabeel, A. E., Y. A. F. El-Samadony, and M. H. Khiera. "Performance evaluation of energy efficient evaporatively aircooled chiller." Applied Thermal Engineering $122 \quad$ (2017): $204-213$. https://doi.org/10.1016/j.applthermaleng.2017.04.103

[13] Sawant, Aditya P., Neeraj Agrawal, and Prasant Nanda. "Performance assessment of an evaporative coolingassisted window air conditioner." International Journal of Low-Carbon Technologies 7, no. 2 (2012): 128-136. https://doi.org/10.1093/ijlct/ctr029

[14] Geppert, Jasmin, and Rainer Stamminger. "Analysis of effecting factors on domestic refrigerators' energy consumption in use." Energy Conversion and Management $76 \quad$ (2013): $794-800$. https://doi.org/10.1016/i.enconman.2013.08.027

[15] Khan, Md Imran Hossen, Hasan MM Afroz, Md Abdur Rohoman, Mohammad Faruk, and Mohammad Salim. "Effect of different operating variables on energy consumption of household refrigerator." International Journal of Energy Engineering 3, no. 4 (2013): 144-150.

[16] Cabello, R., D. Sánchez, Rodrigo Llopis, I. Arauzo, and E. Torrella. "Experimental comparison between R152a and $\mathrm{R} 134$ a working in a refrigeration facility equipped with a hermetic compressor." International Journal of Refrigeration 60 (2015): 92-105. https://doi.org/10.1016/i.ijrefrig.2015.06.021

[17] Setyawan, Andriyanto. "Effects of evaporating temperature on flow pattern in a horizontal evaporator." Frontiers in Heat and Mass Transfer (FHMT) 14 (2020): 1-6. https://doi.org/10.5098/hmt.14.22

[18] Kumbhar, Anil, Nitin Gulhane, and Sachin Pandure. "Effect of various parameters on working condition of chiller." Energy Procedia 109 (2017): 479-486. https://doi.org/10.1016/i.egypro.2017.03.076

[19] Mohd Yunus, Hisamudin, Henry Nasution, Azhar Abdul Aziz, Sumeru, and Afiq Aiman Dahlan. "The Effect of Ambient Temperature on the Performance of Automotive Air-Conditioning System." In Applied Mechanics and Materials, vol. 819, pp. 221-225. Trans Tech Publications Ltd, 2016. https://doi.org/10.4028/www.scientific.net/AMM.819.221

[20] Ribeiro, Guilherme Borges. "Development of a high ambient temperature cooling unit based on microcompressor technology." International Refrigeration and Air Conditioning Conference 1225 (2012). 